\title{
Effects of Inhibitors of RNA and Protein Synthesis on Activation of Glyconeogenesis in Tetrahymena'
}

\author{
MICHAEL R. LEVY 2 \\ Department of Biological Chemistry, University of Michigan, \\ Ann Arbor, Michigan
}

\begin{abstract}
The effects of actinomycin D, puromycin, and p-fluorophenylalanine on the activation of glyconeogenesis in Tetrahymena were studied.

The extent of activation of glyconeogenesis in cultures containing inhibitor was as great as or greater than in the controls, as was the uptake of tracer levels of acetate into glycogen. These increases occurred despite a partial or complete inhibition of synthesis of isocitrate lyase, a glyconeogenic enzyme in Tetrahymena. Washed cells from these cultures could convert tracer or substrate levels of acetate to glycogen at enhanced rates. When glyconeogenesis was activated in starved cells in the presence of inhibitor, there was a negligible increase in the amount of isocitrate lyase, but a significant increase in the rate of glyconeogenesis. The data indicate that glyconeogenesis in Tetrahymena can be activated in the absence of enzyme synthesis.
\end{abstract}

In the ciliate, Tetrahymena pyriformis, the glyoxylate bypass of the tricarboxylic acid cycle is responsible for the conversion of lipids to glycogen. Cells capable of converting acetate to glycogen were found to have elevated levels of malate synthase and isocitrate lyase (Hogg and Kornberg, '63), and the location of $\mathrm{C}^{14}$ in glucose moieties of glycogen was consistent with metabolism of lipids via this pathway (Hogg, '59). In addition, activation of glyconeogenesis leads to an increase in the relative amount of acetate entering cellular metabolic pathways at the level of malate, as compared with that entering at the level of citrate (Levy and Scherbaum, '65b).

Glyconeogenesis in Tetrahymena is readily stimulated by a simple change in growth conditions. When well-shaken, peptonegrown cultures of this organism are transferred to static conditions, increases in the rate of glyconeogenesis and in the ability to convert acetate to glycogen (Levy and Scherbaum, '65a), and in the specific activities of isocitrate lyase (5-10-fold in the $\mathrm{E}$ strain, 2-fold in the GL strain) and malate synthase occur within three hours (Levy, Scherbaum and Hogg, '64; Levy and Scherbaum, '65b). In the present paper, the effects of an amino acid analogue and of inhibitors of RNA and protein synthesis on the activation of glyconeogenesis are tested. Results suggest that activation of this process is not primarily dependent upon synthesis of isocitrate lyase.

\section{MATERIALS AND METHODS}

\section{Cultural procedures}

Cultures of Tetrahymena pyriformis were grown at $28^{\circ}$ in $2 \%(\mathrm{w} / \mathrm{v})$ proteose peptone (Difco) with $0.1 \%(\mathrm{w} / \mathrm{v}) \mathrm{K}_{2} \mathrm{HPO}_{4}$ and $0.1 \%(\mathrm{w} / \mathrm{v})$ liver fraction. The $\mathrm{E}$ strain was used in all experiments except that shown in table 1 , in which the GL strain was used. Cultures were grown in 2 1 penicillin flasks, having a surface area of $225 \mathrm{~cm}^{2}$. To insure good aeration, flasks contained only $250 \mathrm{ml}$ of medium, and were shaken at 70-80 excursions/min on a New Brunswick gyratory shaker. Procedures for harvesting and washing of cells have been described (Levy and Scherbaum, '65a). For experiments on washed cells, organisms were suspended in an inorganic, phosphate-buffered medium (Ryley, '52).

\section{Activation of glyconeogenesis}

Activation of glyconeogenesis was accomplished by transferring well-shaken log phase cultures (or washed cell suspensions from such cultures) to smaller vessels, which were then maintained without shaking for 3-4 hours. Surface to volume ratios were chosen so as to limit respiration to about $5 \%$ of capacity (Levy and Scherbaum, '65a). This treatment also leads to

Received Oct. 11, '66. Accepted Dec. 9, '66.

1 This investigation was supported by a Public Health Service Postdoctoral Fellowship (2-F2-CA-20,201-02) from the National Cancer Institute.

2 Present address: Department of Zoology, University of Michigan, Ann Arbor, Michigan 48104. 
the onset of the stationary growth phase. Before and after transfer, the rate of glyconeogenesis was determined by shaking cells in air. In the case of cultures, duplicate $20-25 \mathrm{ml}$ portions were shaken in $250 \mathrm{ml}$ Erlenmeyer flasks for 30 or 60 minutes. Reactions were terminated by plunging cells into an equal volume of cold $95 \%$ ethanol, and organisms were collected by gentle centrifugation. Glyconeogenesis in washed cells was assayed by shaking duplicate 2.5 $\mathrm{ml}$ portions in $50 \mathrm{ml}$ flasks, with or without $2.5 \mathrm{mg}$ sodium acetate. Approximately 0.05 $\mu \mathrm{c}$ of sodium-2-14 C acetate (sp. act. 20.5 $\mathrm{mc} / \mathrm{mmole}$ ) were included in each flask. Incubations in this case were for two hours, and reactions were terminated by plunging cells into $60 \% \mathrm{KOH}$. Results are expressed in $\mu$ moles glucose formed $/ \mathrm{hr} / \mathrm{mg}$ protein. Under these conditions, when tracer amounts of acetate are added, the level of $\mathrm{C}^{14}$ in glycogen reaches its peak within one hour and then remains constant, at least for another hour, indicating that there is little or no turnover of glycogen (Levy and Scherbaum, '65a). Since this value represents a final level, it is given as the percentage of added isotope that is recovered in glycogen. When substrate levels of acetate are present, $\mathrm{C}^{14}$ incorporation continues linearly during the two hour assay period. In this case, the value is expressed as counts incorporated into glycogen $/ \mathrm{mg}$ protein of cell suspension, as well as the percentage of the total isotope recovered. The latter values have been normalized to the cell suspension having the highest protein concentration for that particular experiment.

\section{Analytical procedures}

Methods for the isolation and estimation of glycogen and for the counting of radioactivity have been described (Levy and Scherbaum, '65a). Protein was determined by the method of Lowry et al. '51, on material that was insoluble after digestion for 15 minutes at $90^{\circ}$ in $3 \%$ perchloric acid. Isocitrate lyase was assayed at three enzyme levels on total cell homogenates. Details have been given previously (Levy and Scherbaum, '65b).

\section{Source of chemicals}

Puromycin was purchased from the Nutritional Biochemical Company. Actinomycin D was a gift from Merck, Sharpe, and Dohme Laboratories. Sodium $2{ }^{14} \mathrm{C}$ acetate was obtained from the Volk Radiochemical Company. Other chemicals were obtained from the California Corporation for Biochemical Research or from the Sigma Chemical Company.

\section{RESULTS}

In initial experiments, cultures of $T$. pyriformis, strain GL, were shaken for very brief periods with tracer levels of acetate after 0 and three hours under static conditions. Isocitrate lyase activity and $\mathrm{C}^{14} \mathrm{up}$ take into glycogen were determined (table 1). Static controls incorporated about 15 times as much tracer into glycogen as did the 0 hour controls. This increase has previously been shown to result from an increase in the relative amount of acetate metabolized via the glyoxylate bypass (Levy and Scherbaum, '65b) and to be accompanied by an increased ability to con-

TABLE 1

Effects of inhibitors on isocitrate lyase induction and incorporation of $\mathrm{C}^{14}$ acetate into glycogen

\begin{tabular}{|c|c|c|c|c|}
\hline \multirow[b]{2}{*}{ Addition } & \multicolumn{2}{|c|}{ Radioactivity } & \multicolumn{2}{|c|}{ Isocitrate lyase } \\
\hline & Zero hour & $\begin{array}{c}\text { Three hour } \\
\text { static }\end{array}$ & Zero hour & $\begin{array}{l}\text { Three hour } \\
\text { static }\end{array}$ \\
\hline & \multicolumn{2}{|c|}{$\begin{array}{c}\text { counts/minute in glycogen/ } \\
10^{6} \text { cells }\end{array}$} & \multicolumn{2}{|c|}{$\begin{array}{l}\text { Mmoles glyoxylate formed } \\
\text { hour/mg protein }\end{array}$} \\
\hline $\begin{array}{l}\text { None } \\
\text { Actinomycin } \mathrm{D}, 10 \mu \mathrm{g} / \mathrm{ml} \\
\text { D.L-p-fluorophenylalanine, }\end{array}$ & 664 & $\begin{array}{l}9,870 \\
9,260\end{array}$ & 1.1 & $\begin{array}{l}1.8 \\
0.9\end{array}$ \\
\hline $\begin{array}{l}2.5 \mathrm{mM} \\
\text { Puromycin, } 40 \mu \mathrm{g} / \mathrm{ml}\end{array}$ & - & $\begin{array}{l}16,000 \\
27,200\end{array}$ & - & $\begin{array}{l}1.0 \\
1.0\end{array}$ \\
\hline
\end{tabular}

Glyconeogenesis was activated by transferring $100 \mathrm{ml}$ portions of a well-shaken, exponentially growing culture into $500 \mathrm{ml}$ Erlenmeyer flasks, and maintaining these for three hours without shaking. Inhibitors were added as indicated. At zero and three hours, 25 ml portions of culture were shaken for $15 \mathrm{minutes}$ with $1.25 \mu \mathrm{c}$ of sodium acetate-2-14C (sp. act. $20.5 \mathrm{mc} / \mathrm{mmole}$ ). 
vert substrate levels of acetate to glycogen (Levy and Scherbaum, '65a). The presence of Act $\mathrm{D},{ }^{3} \mathrm{PM}$, or pFPA during the activation period did not prevent this increase from taking place. In fact, the rate of acetate incorporation in the treated cells was usually even greater than in the activated controls. Other experiments have shown that incorporation of acetate into glycogen in the 0 hour samples is not affected by the inhibitors. In each case, the inhibitor prevented the increase in the specific activity of isocitrate lyase.

In the next set of experiments, rates of net glyconeogenesis in peptone were meas- ured by shaking cultures for a 30 or 60 minute period after 0 and 3 hours under static conditions (table 2). The E strain of T.pyriformis was used in this and all subsequent experiments. Transfer of cultures of this strain from shaken to static conditions leads to a much greater increase of isocitrate lyase. In the three experiments shown, the rates of glycogen synthesis in the 0 hour (log phase) samples were 0.03 $\mu$ moles glucose formed $/ \mathrm{hr} / \mathrm{mg}$ protein or less, while rates in the static controls ranged from 0.13 to 0.23 . In each case

8 Abbreviations: Actinomycin D, Act D; Puromycin, PM; D,L-p-fluorophenylalanine, pFPA.

TABLE 2

Effects of inhibitors on isocitrate lyase induction and activation of glyconeogenesis

\begin{tabular}{|c|c|c|c|c|c|c|c|}
\hline \multirow[b]{2}{*}{ Exper. } & \multirow[b]{2}{*}{ Inhibitor } & \multicolumn{3}{|c|}{ Net glyconeogenesis } & \multicolumn{3}{|c|}{ Isocitrate Iyase } \\
\hline & & $\begin{array}{c}\text { Zero } \\
\text { hour } \\
\text { control }\end{array}$ & $\begin{array}{l}\text { Three } \\
\text { hour } \\
\text { static }\end{array}$ & $\begin{array}{c}\text { Three } \\
\text { hour } \\
\text { static }+ \\
\text { inhibitox }\end{array}$ & $\begin{array}{c}\text { Zero } \\
\text { hour } \\
\text { control }\end{array}$ & $\begin{array}{l}\text { Three } \\
\text { hour } \\
\text { static }\end{array}$ & $\begin{array}{c}\text { Three } \\
\text { hour } \\
\text { static }+ \\
\text { inhibitor }\end{array}$ \\
\hline & & \multicolumn{3}{|c|}{$\begin{array}{c}\text { umoles glucose } \\
\text { formed } / \mathrm{hr} / \mathrm{mg} \text { protein }\end{array}$} & \multicolumn{3}{|c|}{$\begin{array}{c}\text { umoles glyoxylate } \\
\text { formed } / \mathrm{hr} / \mathrm{mg} \text { protein }\end{array}$} \\
\hline 1 & Actinomycin D, $9 \mu \mathrm{g} / \mathrm{ml}$ & 0.03 & 0.18 & 0.21 & 0.8 & 4.4 & 1.6 \\
\hline 2 & $\begin{array}{l}\text { D,L-p-fluorophenyl- } \\
\text { alanine, } 2.5 \mathrm{mM}\end{array}$ & -0.07 & 0.23 & 0.31 & 一 & - & 一 \\
\hline 3 & Puromycin, $48 \mu \mathrm{g} / \mathrm{ml}$ & 0.03 & 0.13 & 0.16 & 0.8 & 3.9 & 1.5 \\
\hline
\end{tabular}

Glyconeogenesis was activated as described in the legend for table 1 . Net glyconeogenesis was tested by shaking duplicate $20 \mathrm{ml}$ portions of culture for one hour (experiments 1 and 3 ) or for 30 minutes (experiment 2).

TABLE 3

Effects of puromycin on activation of glyconeogenesis

\begin{tabular}{|c|c|c|c|}
\hline & $\begin{array}{l}\text { Zero } \\
\text { hour }\end{array}$ & $\begin{array}{l}\text { Three } \\
\text { hour } \\
\text { static }\end{array}$ & $\begin{array}{c}\text { Three } \\
\text { hour } \\
\text { static }+ \\
\text { puromycin }\end{array}$ \\
\hline \multirow{6}{*}{$\begin{array}{l}\text { Cultures } \\
\text { Washed cells } \\
\text { Endogenous } \\
+1 \mathrm{mg} / \mathrm{ml} \text { sodium acetate }\end{array}$} & \multicolumn{3}{|c|}{ Net glyconeogenesis } \\
\hline & \multicolumn{3}{|c|}{$\mu$ moles glucose formed $/ \mathrm{hr} / \mathrm{mg}$ protein } \\
\hline & 0.03 & 0.13 & 0.16 \\
\hline & \multirow[b]{2}{*}{0.11} & \multirow[b]{2}{*}{0.17} & \multirow[b]{2}{*}{0.16} \\
\hline & & & \\
\hline & 0.10 & 0.20 & 0.18 \\
\hline \multirow{3}{*}{$\begin{array}{l}\text { Tracer acetate only ( } \% \text { incorporation) } \\
+1 \mathrm{mg} / \mathrm{ml} \text { sodium acetate } \\
\text { ( } \% \text { incorporation) } \\
\text { (counts } / \text { minute } / \mathrm{mg} \text { protein) }\end{array}$} & \multicolumn{3}{|c|}{$\begin{array}{l}\text { Incorporation of acetate-2-C14 } \\
\text { into glycogen in washed cells }\end{array}$} \\
\hline & 24 & 60 & 51 \\
\hline & $\begin{array}{r}9 \\
674\end{array}$ & $\begin{array}{r}36 \\
2690\end{array}$ & $\begin{array}{r}31 \\
2330\end{array}$ \\
\hline & \multicolumn{3}{|c|}{ Isocitrate lyase } \\
\hline & \multicolumn{3}{|c|}{ 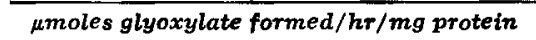 } \\
\hline & 0.8 & 3.9 & 1.5 \\
\hline
\end{tabular}

Glyconeogenesis was activated as described for the previous experiments. Glyconeogenesis in cultures was tested by shaking duplicate $20 \mathrm{ml}$ portions for one hour. Glyconeogenesis in washed cells was tested as described in the Methods section, after cells had been harvested, washed twice, and resuspended in inorganic medium. 
however, static samples treated with inhibitor formed glycogen at an even greater rate than the activated controls, although the increase in the specific activity of isocitrate lyase was largely suppressed.

The last of these experiments was carried out in greater detail (table 3). Before and after the activation period, portions of culture were harvested, washed, and suspended in inorganic medium. Glyconeogenesis was tested by shaking these cells for two hours with tracer or substrate levels of acetate. The rate of synthesis in the presence of acetate in the static controls was twice that of the 0-hour cells, and the rate in the puromycin-treated cells had also nearly doubled. In this particular experiment high endogenous rates of glycogen synthesis were observed. However, in the static samples, acetate was the major precursor when present at substrate levels as indicated by the high percentage of isotope recovered in glycogen. When only tracer levels of acetate were added, over $50 \%$ was incorporated into glycogen, both in static controls and in static cells treated with PM. Such high levels are consistent with metabolism of acetate via the glyoxylate bypass. Thus, PM largely prevented the increase in isocitrate lyase, but not the increased ability to convert acetate to glycogen. Results similar to these have been obtained with cultures treated with Act D and pFPA.

In experiments such as the one just discussed, substantial increases in the specific activity of isocitrate lyase took place, even in the presence of inhibitors. In addition, the endogenous rates of glycogen synthesis were often nearly as great as those obtained in the presence of acetate. The use of starved cells served to eliminate these problems. There was virtually no synthesis of isocitrate lyase when inhibitor was present and the endogenous rates of glyconeogenesis were lowered so that a substantial stimulation was achieved when cells were incubated with substrate levels of acetate. Such a stimulation tends to justify the use of $\mathrm{C}^{14}$ incorporation as an index of net glyconeogenesis from acetate.

In the experiment shown in table 4 , cells from a log phase culture were harvested, washed, and shaken in non-nutrient medium

TABLE 4

Effects of D,L-p-fluorophenylalanine on activation of glyconeogenesis in starved cells

\begin{tabular}{|c|c|c|c|c|c|}
\hline & \multirow{2}{*}{$\begin{array}{l}\text { "Zero" } \\
\text { hour }\end{array}$} & \multicolumn{2}{|c|}{ "Three" hour } & \multicolumn{2}{|c|}{ "Three" hour } \\
\hline & & Shaken & $\begin{array}{l}\text { Shaken } \\
+ \text { pFPA }\end{array}$ & Static & $\begin{array}{c}\text { Static } \\
+ \text { pFPA }\end{array}$ \\
\hline & \multicolumn{5}{|c|}{ Net glyconeogenesis } \\
\hline & \multicolumn{5}{|c|}{ umoles glucose formed $/ \mathrm{hr} / \mathrm{mg}$ protein } \\
\hline \multirow{3}{*}{$\begin{array}{l}\text { Endogenous } \\
+1 \mathrm{mg} / \mathrm{ml} \text { sodium acetate }\end{array}$} & 0.017 & $<0$ & $<0$ & 0.13 & 0.064 \\
\hline & 0.075 & 0.03 & 0.003 & 0.27 & 0.15 \\
\hline & \multicolumn{5}{|c|}{$\begin{array}{l}\text { Incorporation of acetate-2-C14 } \\
\text { into Glycogen }\end{array}$} \\
\hline Tracer acetate only & & & & & \\
\hline (\% incorporation) & 4.9 & 1.5 & 1.1 & 26 & 24 \\
\hline$+1 \mathrm{mg} / \mathrm{ml}$ sodium acetate & & & & & \\
\hline (\% incorporation) & 4.7 & 4.4 & 0.3 & 22 & 11 \\
\hline \multirow{3}{*}{$\begin{array}{l}\text { (Counts/min/ } \\
\text { mg protein) }\end{array}$} & & & & & \\
\hline & 1160 & 1100 & 70 & 5510 & 2650 \\
\hline & \multicolumn{5}{|c|}{ Isocitrate lyase } \\
\hline $\begin{array}{l}\text { Specific activity ( } \mu \text { moles gly- } \\
\text { oxylate } / \mathrm{hr} / \mathrm{mg} \text { protein) }\end{array}$ & 1.1 & 1.0 & 0.6 & 2.5 & 1.4 \\
\hline Units/ml cell suspension & & & & & \\
\hline Initial & & 0.46 & 0.54 & 0.50 & 0.48 \\
\hline Final & & 0.36 & 0.27 & 1.0 & 0.53 \\
\hline
\end{tabular}

Washed cells from growing cultures were sugpended in inorganic medium and preincubated by shaking for three hours. Cells were then collected and resuspended in inorganic medium. One aliquot was tested immediately for glyconeogenesis in the presence of substrate or tracer levels of acetate, as described for table 3 . The other portions were each diluted to $120 \mathrm{ml}$ and were either shaken or maintained under static conditions for three hours, in the presence or absence of $0.25 \mathrm{mM} D, \mathrm{~L}-\mathrm{p}$-fluorophenylalanine. In the shaken samples, $30 \mathrm{ml}$ of cell suspension were transferred to each of four $500 \mathrm{ml}$ flasks. For the static samples, 120 ml were placed in a single $500 \mathrm{ml}$ flask. The initial protein concentration was about $0.45 \mathrm{mg} / \mathrm{ml}$. After three hours, samples were collected and rates of glyconeogenesis were tested. 
for three hours prior to treatment. After this preincubation cells were either shaken for an additional three hours or maintained under static conditions for three hours in the presence or absence of pFPA (table 4). Cells were then washed and tested for glyconeogenesis in the usual manner, by shaking for two hours in the presence of tracer or substrate levels of acetate. Cells shaken either with or without inhibitor showed a decreased rate of glyconeogenesis as compared with the " 0 " hour control. The rate of net synthesis in the presence of acetate decreased from a value of 0.075 in the " 0 " hour sample to 0.03 in the shaken controls, and to 0.003 in cells shaken with inhibitor. Cells from these suspensions had little ability to incorporate substrate or tracer levels of acetate into glycogen. In the shaken cells, both the specific activity and the amount of isocitrate lyase decreased. In contrast, statically maintained cells showed a greatly increased capacity for glycogen synthesis when compared with the " 0 " hour sample and especially when compared with the cells that were shaken for three hours. The rate of synthesis in the presence of acetate was 0.27 $\mu$ moles glucose $/ \mathrm{hr} / \mathrm{mg}$ protein in the static controls and $0.15 \mu$ moles glucose $/ \mathrm{hr} / \mathrm{mg}$ protein in cells treated with inhibitor. The incorporation of tracer and substrate levels of acetate into glycogen also increased greatly. It can be seen that the static controls were able to synthesize a substantial amount of isocitrate lyase, even after several hours in non-nutrient medium, and despite a net decrease in total cell protein. The presence of pFPA greatly limited the increase in both the specific activity and the net amount of isocitrate lyase. Thus, the increase in glyconeogenic capacity resulted mainly from an activation of the glyoxylate bypass. The inhibitor itself did not lead to an increased rate of glyconeogenesis, since cells that had been shaken for three hours with pFPA had a negligible rate.

It would appear that the greater rate of glyconeogenesis in the static controls may be the result of synthesis of isocitrate lyase and, possibly, other glyconeogenic enzymes. Thus, in both the uninhibited and the inhibited samples, glyconeogenesis was activated, but the increase in glyconeo- genic enzymes in the uninhibited cells permitted this process to proceed at a greater rate. The fact that in the pFPA-treated cells the final level in glycogen of $\mathrm{C}^{24}$ from tracer levels of acetate was about the same as in the static controls further shows that the shift in metabolism took place.

\section{DISCUSSION}

These results suggest that the amount of enzyme of the glyoxylate bypass is not the primary factor controlling glyconeogenesis in Tetrahymena. Thus, addition of Act D, PM, or pFPA to cultures or to washed cell suspensions at the beginning of the period of restricted aeration greatly limited the increase of isocitrate lyase. However, a considerable increase in the capacity for glyconeogenesis could still take place. In fact, when rates of glycogen synthesis were measured in cultures, cells treated with inhibitor usually exhibited an even greater increase than did the activated controls.

When freshly washed cells from activated cultures were shaken with acetate a considerable proportion of this substrate (over $50 \%$ ) was converted to glycogen, as shown in table 3. The presence of PM, at levels which prevented most of the increase in isocitrate lyase activity only slightly inhibited this conversion. In experiments not shown here, high levels of radioactivity from $2-{ }^{14} \mathrm{C}$ acetate were found in glycogen after cells had been activated in the presence of Act $D$ of pFPA.

More recent experiments also suggest that glyconeogenesis in Tetrahymena can be stimulated by activation mechanisms alone. Thus, incubation of cells under atmospheres of $0.5-2 \%$ oxygen leads to an activation of glyconeogenesis, but little increase in the specific activity of isocitrate lyase or malate synthase is usually obobserved (unpublished data).

Although glyconeogenesis can be activated without enzyme synthesis, the data of table 4 show that a greater rate may sometimes be obtained if enzyme synthesis does occur. The same experiment tends to rule out the possibility that increases in enzymes other than those of the glyoxylate bypass govern the activation of glyconeogenesis in Tetrahymena. It has been pointed out (Krebs and Kormberg, '57) that for a net reversal of glycolysis to occur, the 
phosphofructokinase and pyruvate kinase steps must be circumvented. An induction of fructose-1,6-diphosphatase, which bypasses the first of these steps occurs when various microorganisms are grown on noncarbohydrate-containing medium (Gotto and Pogell, '62; Cancedo, Salas, Giner and Sols, '65). It also increases in mammalian tissue under the influence of glucocorticoids (Weber, Singhal, Stamm, Fisher and Mentendiek, '64). Similarly phosphoenolpyruvate carboxykinase has been shown to increase in mammalian livers when animals are in a gluconeogenic state (Shrago, Lardy, Nordlie and Foster, '63). Although variations in the specific activities of these enzymes have not been tested in Tetrahymena, ${ }^{4}$ it is unlikely that substantial increases could have occurred under the experimental conditions of table 4 , where glyconeogenesis was activated in starved cells that were treated with pFPA. In further support of this view is the finding that activation of glyconeogenesis in this organism involves a change in the initial reactions of acetate, relatively more of this compound appearing initially in malate as compared with citrate. In mammalian systems, gluconeogenesis can also be activated without increase in the amount of enzyme. Thus, hydrocortisone could stimulate gluconeogenesis when phosphopyruvate carboxykinase increase was prevented by Act D (Ray, Foster and Lardy, '64). Similarly, this inhibitor did not abolish a triamcinolone-induced gluconeogenesis, although enzyme levels were not measured (Haynes, '65).

It has previously been suggested (Hogg and Kornberg, '63) that glyconeogenesis in Tetrahymena is controlled by changes in the intracellular distribution of isocitrate lyase and malate synthase. However, little difference was found in the relative distribution of these two enzymes when glyconeogenesis was stimulated by the methods described here (unpublished data).

The role of the glyoxylate bypass in glycogen storage, as well as its possible role in circumvention of the tricarboxylic acid cycle under conditions of oxygen limitation have been discussed in terms of the adaptive value to the cell (Hogg and Kornberg, '63); Levy and Scherbaum, '65a and b; Hogg, '65). The experiments presented here further indicate the powerful capacity of Tetrahymena to activate this pathway.

\section{ACKNOWLDEGMENT}

Provision of laboratory facilities by $\mathrm{Dr}$. J. F. Hogg is acknowledged.

\section{LITERATURE CITED}

Cancedo, C., M. L. Salas, A. Giner and A. Sols 1965 Reciprocal effects of carbon sources on the levels of an AMP sensitive fructose-1,6diphosphatase and phosphofructokinase in yeast. Biochem. Biophys. Res. Commun., 20: 15.

Gotto, A., and G. N. Pogell 1962 Induction of fructose-1,6-diphosphatase activity in Escherichia coli. Biochem. Biophys. Res. Commun., 9: 38.

Haynes, R. C., 1965 The control of gluconeogenesis by adrenal cortical hormones. Advances in Enzyme Regulation, 3: 111.

Hogg, J. F. 1959 Glycogen synthesis from fatty acids in Tetrahymena. Fed. Proc., 18: 247.

1965 Energy metabolism in ciliates. Progress in protozoology, p. 74.

Hogg, J. F., and H. L. Kornberg 1963 The metabolism of $\mathrm{C}_{2}$-compounds in micro-organisms. 9. Role of the glyoxylate cycle in protozoal glyconeogenesis. Biochem. J., 86: 462.

Krebs, H. A., and H. L. Kornberg 1957 Energy Transformation in Living Matter. Springer Verlag, (Berlin).

Levy, M. R., and O. H. Scherbaum 1965a Glyconeogenesis in growing and non-growing cultures of Tetrahymena pyriformis. J. Gen. Microbiol., 38: 221.

1965b Induction of the glyoxylate cycle in Tetrahymena. Arch. Biochem. Biophys., 109: 116.

Levy, M. R., O H. Scherbaum and J. F. Hogg 1964 Activation of glyconeogenesis in Tetrahymena pyriformis. Fed. Proc., 23: 320.

Lowry, O. H., H. J. Rosebrough, A. L. Farr and R. J. Krandall 1951 Protein measurements with the folin phenol reagent. J. Biol. Chem., 193: 265.

Ray, P. D., D. O. Foster and H. A. Lardy 1964 Gluconeogenesis stimulated by hydrocortisone independently of "De Novo" synthesis of enzymes. Fed. Proc., 23: 482.

Ryley, J. F., 1952 Studies on the metabolism of protozoa. 3. Metabolism of the ciliate Tetrahymena pyriformis (Glaucoma pyriformis). Biochem. J., 52: 483.

Shrago, E., H. A. Lardy, R. C. Nordlie and D. O. Foster 1963 Metabolic and hormonal control of phosphenolpyruvate carboxykinase and $\mathrm{ma}$ lic enzyme in rat liver. J. Biol. Chem., 238: 3188.

Weber, G., R. L. Singhal, N. B. Stamm, E. A. Fisher and M. A. Mentendiek 1964 Regulation of enzymes involved in gluconeogenesis.

4 It has recently been shown that the level of PEP carboxykinase in Tetrahymena was higher in cells grown in the absence of glucose, and which could therefore presumably perform glyconeogenesis, than in cells grown in the presence of glucose (E, Shrago and 